\title{
FAIR ENOUgh? The NATIONAL SECURITY INFORMATION (CRIMINAL AND CIVIL Proceedings) ACt 2004
}

\section{LUKE BECK*}

The need to combat terrorism has resulted in a need for changes to the legal process to take account of the realities of national security. One important change has been the introduction of legislation to govern the disclosure of national security-sensitive information to participants in legal proceedings. This, of course, raises a number of issues including concerns about ensuring fairness to the participants. This article considers whether the National Security Information (Criminal and Civil Proceedings) Act 2004 is consistent with the right to a fair trial found in the International Covenant on Civil and Political Rights to which Australia is a party. The conclusion is that the legislation is consistent with that right.

\section{INTRODUCTION}

The Australian parliament has enacted dozens of pieces of legislation in recent years dealing with the topic of terrorism. ${ }^{1}$ Among other things, that legislation has created new criminal offences and expanded the powers of law enforcement and security agencies. That legislation has also altered how information relating to national security matters is dealt with in court proceedings within federal jurisdiction. Traditionally, this has been a matter for public interest immunity claims at common law. However, following the ordering of a stay by the Supreme Court of the Australian Capital Territory in a federal espionage case because a successful public interest immunity claim

\footnotetext{
* BJuris, LLB(Hons) UNSW, LLM Candidate USyd; Public Servant, New South Wales. The views expressed in this paper are those of the author.

${ }^{1}$ For a brief overview see, eg, Australian Human Rights Commission, A Human Rights Guide to Australia's Counter-terrorism Laws <www.hreoc.gov.au/human_rights/counter_terrorism/ index.html $>$.
} 
would have resulted in an unfair trial, ${ }^{2}$ parliament enacted legislation to govern the disclosure of information relating to national security in court proceedings. ${ }^{3}$ How information relating to national security matters is dealt with in proceedings within federal jurisdiction is now primarily a matter governed by the National Security Information (Criminal and Civil Proceedings) Act 2004 (Cth) ('NSI Act').

Lord Diplock once said that '[t]he fundamental human right is not to a legal system that is infallible but to one that is fair'. ${ }^{4}$ A core aspect of a fair legal system is the right to a fair hearing. This is a right that is protected by international law. This article examines whether the NSI Act ensures that the requirements of a fair hearing will be met in those cases which it governs. The article proceeds in the following manner: first, it briefly outlines the scheme of the NSI Act; second, it considers the NSI Act in light of the right to a fair hearing at international law. It does this by considering the two key aspects of that right: the notion of a fair hearing; and the nature of the body before which such a hearing must be had. Ultimately, it will be seen that the NSI Act does not appear to violate those requirements.

\section{The SCHEME OF THE NSI ACT}

The object of the NSI Act is to

prevent the disclosure of information in federal criminal proceedings and civil proceedings where the disclosure is likely to prejudice national security, except to the extent that preventing the disclosure would seriously interfere with the administration of justice. ${ }^{5}$

The Act defines 'national security' broadly to mean 'Australia's defence, security, international relations or law enforcement interests'. ${ }^{6}$ Each of those

${ }^{2} R v$ Lappas and Dowling [2001] ACTSC 115 (26 November 2001); $R$ v Lappas (2003) 152 ACTR 7. A summary of this litigation is provided in Australian Law Reform Commission 'Keeping Secrets: The Protection of Classified and Security Sensitive Information' Report No 98 (2004), Appendix 4.

${ }^{3}$ See Explanatory Memorandum, National Security Information (Criminal Proceedings) Bill 2004; Commonwealth, Parliamentary Debates, House of Representatives, 27 May 2004 (Second Reading Speech) 29307 (Phillip Ruddock, Attorney-General).

${ }^{4}$ Maharaj v Attorney-General of Trinidad and Tobago (No 2) [1979] AC 385, 399.

${ }^{5}$ NSI Act s 3(1).

${ }^{6}$ Ibid s 8 . 
terms, except for 'defence', is also defined in broad terms. ${ }^{7}$

Part 3 of the Act establishes the regime in respect of federal criminal proceedings. ${ }^{8}$ Where the prosecutor or defendant knows or believes that he or she will disclose information that relates to or may affect national security, or that a person intended to be called as a witness will disclose information that relates to or may affect national security in giving evidence or will do so by the mere presence of the witness, the prosecutor or defendant must give the Attorney-General notice in writing of that knowledge or belief. ${ }^{9}$ The court must also be advised in writing and on receipt of such advice the court 'must' adjourn the proceeding. ${ }^{10}$

Where the Attorney-General receives a notice from a prosecutor or defendant and considers that disclosure of the relevant information is 'likely' to prejudice national security, the Attorney-General has two options where the information is in the form of a document. First, the Attorney-General may give each potential discloser of the information in the proceeding any of: (i) a copy of the document with the information deleted, (ii) a copy of the document with the information deleted and a summary of the information attached to the document, or (iii) a copy of the document with the information deleted and a statement of facts that the information would, or would be likely to, prove attached to the document. Where any of those types of copies are issued the Attorney-General will also issue a certificate which describes the information and states that the potential discloser must not, except in permitted circumstances, ${ }^{11}$ disclose the information but may disclose the copy, or the copy and the statement or summary. ${ }^{12}$

The second option available to the Attorney-General on receipt of a notice is to issue a certificate that describes the information and states that the potential discloser must not, except in permitted circumstances, disclose the information. ${ }^{13}$ Similar options are available to the Attorney-General where the

\footnotetext{
${ }^{7}$ Ibid ss 9-11.

${ }^{8}$ As to what is a 'federal criminal proceeding', see NSI Act ss 13-14.

${ }^{9}$ Ibid s 24.

${ }^{10}$ Ibid s 24(3)-(4).

${ }^{11}$ Ibid s 16 defines 'permitted circumstances'.

${ }^{12}$ Ibid s 26(2)(a).

${ }^{13}$ Ibid s 26(2)(b).
} 
relevant information is not in the form of a document. ${ }^{14}$ In any case the Attorney-General may decide not to issue a certificate. ${ }^{15}$

The Attorney-General's certificate and its conditions are, however, in effect only an interim measure. ${ }^{16}$ Where the Attorney-General issues a certificate the court must hold a hearing to decide which of a number of orders should be made. ${ }^{17}$ The court can order that the information, regardless of its form, may or may not be disclosed in the proceeding ${ }^{18}$ or, where the information is in the form of a document, that a copy of the document may be disclosed with the information deleted, with or without a summary of the information attached, or may be disclosed with a statement of facts that the information would, or would be likely to, prove attached. ${ }^{19}$

In deciding which order to make, the court must consider a number of factors including whether, having regard to the Attorney-General's certificate, there would be a risk of prejudice to national security if the information were disclosed and whether any order would have a 'substantial adverse effect' on the defendant's right to receive a fair hearing, including in particular on the conduct of his or her defence. ${ }^{20}$ Any risk to national security must be given the 'greatest weight' in the court's consideration. ${ }^{21}$

The hearing conducted must be closed $^{22}$ and if the court considers that the information the subject of the hearing would be disclosed to the defendant or any legal representative of the defendant who does not have an appropriate security clearance, the court may order that that person (or persons) is not entitled to be present at those times. ${ }^{23}$ The defendant has a right to be heard regarding the question of non-disclosure. ${ }^{24}$ Part $3 \mathrm{~A}$ of the NSI Act establishes an equivalent scheme with respect to civil proceedings.

\footnotetext{
${ }^{14}$ Ibid s 26(3).

${ }^{15}$ Ibid s 26(7).

${ }^{16}$ Ibid s 27(1).

${ }^{17}$ Ibid s 27(3)-(4).

${ }^{18}$ Ibid s 31(4)-(5).

${ }^{19}$ Ibid s 31(2).

${ }^{20}$ Ibid s 31(7).

${ }^{21}$ Ibid s 31(8).

${ }^{22}$ Ibid s 27(5). These requirements are set out in s 29(2).

${ }^{23}$ Ibid s 29(3).

${ }^{24}$ Ibid s 29(4).
} 


\section{THE RIGHT TO A FAIR HEARING UNDER INTERNATIONAL LAW}

In 1980, the International Covenant on Civil and Political Rights ${ }^{25}$ ('ICCPR') entered into force for Australia. Article 14 of the ICCPR deals with what is often called the right to a fair hearing. The United Nations Human Rights Committee ('Human Rights Committee') has described that right as 'a key element of human rights protection [which] serves as a procedural means to safeguard the rule of law'. ${ }^{26}$ In the view of Judge Patrick Robinson, President of the International Criminal Tribunal for the Former Yugoslavia, it is 'beyond dispute' that Article 14 reflects customary international law. ${ }^{27}$

Whilst Article 14 is not included in the list of non-derogable provisions in Article 4 of the ICCPR, this does not mean that all of the protections it provides for can be derogated from. The Human Rights Committee has said: 'The guarantees of fair trial may never be subject to measures of derogation that would circumvent the protection of non-derogable rights. ${ }^{28}$ The Human Rights Committee has also stated that 'the principles of legality and the rule of law require that fundamental requirements of fair trial must be respected during a state of emergency'. ${ }^{29}$ The President of the International Criminal Tribunal for the Former Yugoslavia has also suggested that aspects of the right to a fair hearing may be jus cogens in character. ${ }^{30}$ Thus, at least some of the protections provided for are particularly important in human rights terms. ${ }^{31}$

${ }^{25}$ International Covenant on Civil and Political Rights, opened for signature 19 December 1966, 999 UNTS 171 (entered into force 23 March 1976).

${ }^{26}$ Human Rights Committee, General Comment No 32: Right to Equality before Courts and Tribunals and to a Fair Trial, $90^{\text {th }}$ sess, UN Doc CCPR/C/GC/3 (23 August 2007) [2] ('General Comment No 32').

27 Judge Patrick Robinson, 'The Right to a Fair Trial in International Law, with Specific Reference to the Work of the ICTY' (2009) 3 Berkeley Journal of International Law Publicist 1,5 .

${ }^{28}$ General Comment No 32, UN Doc CCPR/C/GC/3, [6].

${ }^{29}$ Human Rights Committee, General Comment No 29: States of Emergency (Article 4), $1950^{\text {th }}$ mtg, UN Doc CCPR/C/21/Rev.1/Add.11 (31 August 2001, adopted 24 July 2001) [16].

${ }^{30}$ Robinson, above n 28,7 .

${ }^{31}$ Schmid has attempted to identify which protections are non-derogable. See, eg, Evelyn Schmid, 'The Right to a Fair Trial in Times of Terrorism: A Method to Identify the NonDerogable Aspects of Article 14 of the International Covenant on Civil and Political Rights' (2009) 1(1) Goettingen Journal of International Law 29; and Evelyne Schmid, The Right to a Fair Trial in States of Emergencies: Non-Derogable Aspects of Article 14 of the International Covenant on Civil and Political Rights (Masters Thesis, Tufts University, 2008) $<$ http://hdl.handle.net/10427/52891>. 
Australia has in place a number of reservations with respect to Article 14 . Whilst it is beyond the scope of this article to consider the validity of those reservations, it is sufficient for present purposes to note that there is no reservation with respect to paragraph 1 of the Article. The first two sentences of that paragraph provide:

All persons shall be equal before the courts and tribunals. In the determination of any criminal charge against him, or of his rights and obligations in a suit at law, everyone shall be entitled to a fair and public hearing by a competent, independent and impartial tribunal established by law.

The NSI Act will be considered with respect to (i) the requirement of a fair hearing, and (ii) the requirement that such a hearing be conducted by a competent, independent and impartial tribunal established by law. By the terms of Article 14, those requirements apply both to criminal and civil proceedings. ${ }^{32}$

\section{The REQUiREMENT FOR A FAIR HEARING}

The fair hearing requirement is a core component of Article 14. It is, however, well-established that fairness is not an inflexible concept. Thus, the Supreme Court of the United States has said, 'Due process of law requires that the proceedings shall be fair, but fairness is a relative, not an absolute concept. It is fairness with reference to particular conditions or particular results. ${ }^{33}$ Similarly, the European Court of Human Rights has held that a fair hearing guarantee 'does not impose a uniform, unvarying standard to be applied irrespective of the context, facts and circumstances' ${ }^{34}$ But this does not mean that there are no minimum requirements. The House of Lords, considering the Convention for the Protection of Human Rights and Fundamental Freedoms (European Convention on Human Rights) ${ }^{35}$ fair hearing obligation, ${ }^{36}$ has held

\footnotetext{
${ }^{32}$ On the meaning of 'rights and obligations in a suit at law' see General Comment No 32, UN Doc CCPR/C/GC/3, [16]-[17].

${ }^{33}$ Snyder v Massachusetts 291 US 97, 116 (1934).

${ }^{34}$ A v United Kingdom (2009) 49 EHRR 29 [203].

35 Convention for the Protection of Human Rights and Fundamental Freedoms, opened for signature 4 November 1950, 213 UNTS 221 (entered into force 3 September 1953).

${ }^{36}$ Ibid art 6.
} 
that 'the concept of fairness imports a core, irreducible minimum of procedural protection'. ${ }^{37}$

The question therefore is: do the procedures provided for by the NSI Act enable a hearing to be held that can, in all of the circumstances, be described as satisfying the minimum requirements of fairness? That question must be asked and answered twice since two distinct hearings are relevant. The first is the hearing under the NSI Act in which the court determines whether or not, and if so, in what form, disclosure of national security information may be made. The second is the substantive criminal or civil proceedings to which the disclosure hearing is related. Both the Human Rights Committee ${ }^{38}$ and the European Court of Human Rights ${ }^{39}$ have considered that the fair hearing obligation extends to the pre-trial stage of substantive proceedings.

To answer that question, the minimum requirements of fairness must be identified. Among other things, a fair hearing obviously includes a right to be heard. Stated more fully, it is a right to be heard with respect to the determination of any criminal charge, or of rights and obligations in a suit at law. This principle is often referred to as being part of the requirement of 'equality of arms' - the requirement that both sides of the argument should be on a relatively similar procedural footing. ${ }^{40}$ Sixty years ago, Lord Denning captured the gist of what appears to be the position at international law with respect to a fair hearing when he said in a different context:

If the right to be heard is to be a real right which is worth anything, it must carry with it a right in the accused man to know the case which is made against him ... and then he must be given a fair opportunity to correct or contradict [that case]. ${ }^{41}$

\footnotetext{
${ }^{37}$ Secretary of State for the Home Department $v$ MB [2007] UKHL 46 [43]; Secretary of State for the Home Department $v A F$ [2009] UKHL 28 [12].

${ }^{38}$ Human Rights Committee, Communication No. 138/1983: Democratic Republic of the Congo, $27^{\text {th }}$ sess, UN Doc CPR/C/27/D/138/1983 (26 March 1986) annex [8.2].

${ }^{39}$ Imbrioscia v Switzerland (1993) 275 Eur Court HR (ser A) [36].

${ }^{40}$ De Haes and Gijsels v Belgium [1997] I Eur Court HR [53]. It should be noted that the Human Rights Committee on some occasions appears to consider that 'equality of arms' is a protection 'in addition to the principles mentioned in the second sentence of Article 14, paragraph 1': General Comment No 32 [8]; whereas on others, it considers 'equality of arms' to be part of that protection: Human Rights Committee, Decision: Communication No 207/1986, 36 ${ }^{\text {th }}$ sess, UN Doc CCPR/C/36/D/207/1986 (28 July 1989) annex [9.3] ('Morael $v$ France'); Human Rights Committee, Decision: Communication No 514/1992, $53^{\text {rd }}$ sess, UN Doc CCPR/C/53/D/514/1992 (26 April 1995) annex [8.4] ('Fei v Colombia').

${ }^{41}$ Kanda v Government of Malaya [1962] AC 322, 337.
} 
This understanding of what a fair hearing entails, as it exists in international human rights law, is not new. In 1978 the European Commission on Human Rights held that it is a requirement of a fair hearing that 'both sides of the case are heard'. ${ }^{42}$ Likewise, in 1997 the European Court of Human Rights

reiterate[d] that the principle of equality of arms - a component of the broader concept of a fair trial — requires that each party must be afforded a reasonable opportunity to present his case under conditions that do not place him at a substantial disadvantage vis-à-vis his opponent. ${ }^{43}$

In more recent times, the European Court of Human Rights has considered the impact of non-disclosure of evidence on the right to a fair hearing in a national security context.

In Chahal $v$ United Kingdom ${ }^{44}$ the European Court of Human Rights considered a judicial procedure for reviewing the lawfulness of detention pending deportation that did not involve the affected individual being provided with even a general summary of the allegations against him and which did not involve any element of adversarial argument before a court. It was held that that procedure could not lead to a valid determination of the lawfulness of detention by a court as required by Article 5(4) of the European Convention on Human Rights. In Av United Kingdom, ${ }^{45}$ a Grand Chamber of the European Court of Human Rights considered the general fair hearing obligation of Article 6 of the European Convention on Human Rights. The Court noted, as it had done before, that in limited circumstances, including those relating to national security, full disclosure of evidence and ordinary adversarial argument may not always be possible. ${ }^{46}$ The Court held, however, that there will not be fair hearing 'unless any difficulties caused to the defendant by a limitation on his rights are sufficiently counterbalanced by the procedures followed by the judicial authorities'. ${ }^{47}$

The Court considered that:

it was essential that as much information about the allegations and evidence against each applicant was disclosed as was possible without compromising national security or the safety of others. Where full disclosure was not

\footnotetext{
${ }^{42}$ Ensslin, Baader and Raspe v Federal Republic of Germany (1978) 14 Eur Comm HR 91 [21]

${ }^{43}$ De Haes and Gijsels v Belgium [1997] I Eur Court HR [53].

${ }^{44}$ [1996] V Eur Court HR 1831.

${ }^{45}$ (2009) 49 EHRR 29.

${ }^{46}$ Ibid [205]-[206].

${ }^{47}$ Ibid [205].
} 
possible, ... [the fair hearing obligation] required that the difficulties this caused were counterbalanced in such a way that each applicant still had the possibility effectively to challenge the allegations against him. ${ }^{48}$

The Court went on to recognise that the use of 'special advocates' could be a useful counterbalance to a lack of full disclosure and ordinary adversarial argument. ${ }^{49}$ A special advocate may see the confidential material and make submissions in the affected person's interests, including with respect to that material, while at the same time not disclosing that material to the person or their ordinary legal representatives. ${ }^{50}$ The Court continued:

However, the special advocate could not perform this function in any useful way unless the detainee was provided with sufficient information about the allegations against him to enable him to give effective instructions to the special advocate. $^{51}$

Whether this has occurred 'must be decided on a case-by-case basis'. 52 The Court suggested that where most of the evidence remains undisclosed but where 'sufficiently specific' allegations are put to the individual, such as that he attended a particular terrorist training camp at a stated location between stated dates, it should be possible for the individual to provide instructions relevant to rebutting the undisclosed evidence, such as an alibi or an innocent explanation for his presence there. ${ }^{53}$

The decision of the European Court of Human Rights was applied by the House of Lords in Secretary of State for the Home Department $v$ AF. ${ }^{54}$ The House of Lords held, consistently with the decision of the European Court, that a person:

must be given sufficient information about the allegations against him to enable him to give effective instructions ... [to his special advocate] in

\footnotetext{
${ }^{48} \operatorname{Ibid}[218]$.

${ }^{49}$ Ibid [233].The use of other techniques has also been suggested in Chahal v United Kingdom [1996] V Eur Court HR 1831 [131].

50 See, eg, Martin Chamberlain, 'Special Advocates and Procedural Fairness in Closed Proceedings' (2009) 28(3) Civil Justice Quarterly 314; United Kingdom, Treasury Solicitor's Department (2006) Special Advocates: A Guide to the Role of Special Advocates and the Special Advocates Support Office (SASA), <www.attorneygeneral.gov.uk/SiteCollection Documents/Special_Advocates.pdf $>$.

${ }^{51}$ A v United Kingdom (2009) 49 EHRR 29 [220].

${ }^{52}$ Ibid.

${ }^{53}$ Ibid.

${ }^{54}$ [2009] UKHL 28.
} 
relation to those allegations. Provided that this requirement is satisfied there can be a fair trial notwithstanding that the ... [affected person] is not provided with the detail or the sources of the evidence forming the basis of the allegations. ${ }^{55}$

It follows that 'non-disclosure cannot go so far as to deny a party knowledge of the essence of the case against him'.

There is other support for the European position that a fair hearing requires disclosure of the essence of the case against a person and an opportunity to effectively challenge that case. The Human Rights Committee has said that each side in a proceeding must be 'given the opportunity to contest all the arguments and evidence adduced by the other party', ${ }^{57}$ and that arguments must be 'open to challenge by the parties' ${ }^{58}$ Similarly, the United Nations Special Rapporteur on the Promotion and Protection of Human Rights and Fundamental Freedoms while Countering Terrorism in his 2008 report noted that it is a requirement of a fair hearing that 'the person concerned [must be allowed] to answer the case [made against him or her]'. ${ }^{59}$ The Special Rapporteur also noted that the right includes the right 'to be aware of, and [be] able to respond to, the case'. ${ }^{60}$ Likewise, the Supreme Court of Canada has held that 'a fair hearing requires that the affected person be informed of the case against him or her, and be permitted to respond to that case'. ${ }^{61}$

Turning now to the NSI Act, can it be said that the Act allows an affected person to be informed of the essence of the case against him or her and ensures an opportunity to effectively challenge that case?

\section{A The Disclosure Proceedings}

In relation to the disclosure hearing, section 29(4) of the NSI Act provides:

If, at the hearing, the prosecutor or ... [the Attorney-General or his or her legal representative] argues that any information should not be disclosed, or

\footnotetext{
${ }^{55}$ Ibid [59].

${ }^{56}$ Ibid [65].

${ }^{57}$ General Comment No 32, UN Doc CCPR/C/GC/3, [13].

${ }^{58}$ Morael v France, UN Doc CCPR/C/36/D/207/1986, annex [9.4].

${ }^{59}$ Martin Scheinin, Special Rapporteur, Protection of human rights and fundamental freedoms while countering terrorism, GA Res 62/159, $63^{\text {rd }}$ sess, Agenda Item 67 (c), UN Doc A/63/223, (6 August 2008), [38].

${ }^{60}$ Ibid [45].

${ }^{61}$ Charkaoui v Canada [2007] 1 SCR. 350, [52].
} 
that the witness should not be called to give evidence, in the proceeding, the defendant and any legal representative of the defendant must be given the opportunity to make submissions to the court about the argument that the information should not be disclosed or the witness should not be called.

On its face, that provision appears to allow an affected person to be heard as to whether or not there should be disclosure. Indeed, it mandates such a course through the use of the word 'must'. As a matter of construction, it would appear that the essence of the 'argument that the information should not be disclosed or the witness should not be called' must be disclosed to the affected person. The provision does not provide merely an opportunity to make submissions to the court about the general issue of disclosure. Rather, it provides a more specific right to make submissions to the court 'about the argument' for non-disclosure. For that opportunity to be meaningful the essence of the argument for non-disclosure must be made known. Indeed, how could an affected person make submissions about an argument of which the person knows nothing?

Moreover, it would not be sufficient to disclose the essence of the argument only to an affected person's legal representative since 'the defendant and any legal representative of the defendant' are entitled to be heard. This requirement would not seem to be overridden by the power given to the court to exclude the affected person and his or her legal representatives from the hearing whilst details of the national security information are given to the court. $^{62}$ The provision requires that the essence of the argument against disclosure be disclosed to the affected person and his or her legal representatives, albeit in a manner that does not disclose the information subject to the argument against disclosure. It should also be noted that the Supreme Court of New South Wales has considered that the expression 'any legal representative of the defendant' is wide enough to include a special advocate who may be given greater disclosure and who may be present when the sensitive information is discussed. ${ }^{63}$

The NSI Act non-disclosure procedure compares favourably with the Canadian approach. Under section 38 of the Canada Evidence Act ${ }^{64}$ there is a requirement of participants in proceedings to notify the Attorney-General if they intend to rely upon information that may injure national security. The initial stages of the procedure are similar to the NSI Act procedure. The Attorney-General may authorise disclosure, including disclosure subject to

${ }^{62}$ NSI Act s 29(3).

${ }^{63} R v$ Lodhi (2006) 163 A Crim R 475 [29].

${ }^{64}$ RSC 1985, c C-5. 
conditions, or may apply to the Federal Court of Canada for a non-disclosure order. If the Federal Court considers that disclosure of the information would not be injurious to national security, it may order the disclosure of the information. If the Federal Court considers that disclosure would be injurious it may authorise the disclosure of all the information, part of the information, a summary of the information and an admission of facts relating to the information subject to conditions designed to limit any injury to national security. Alternatively, the Federal Court may confirm the prohibition on disclosure. An affected person has no right to make submissions with respect to the question of disclosure ${ }^{65}$ Even if the Federal Court orders disclosure, the Attorney-General may issue a certificate prohibiting disclosure which takes effect despite the decision of the Federal Court. ${ }^{66}$ That certificate may only be varied by the Federal Court of Appeal on the ground that the information covered by it does not relate to national security. ${ }^{67}$

The Australian legislation appears to provide a more reasonable procedure for the determination of the question of disclosure of national security-sensitive information. It demands adversarial argument, with the affected person having knowledge of the arguments against disclosure, whereas the Canadian legislation does not. The Australian disclosure hearings would appear to satisfy the international law requirements that the essence of the case be disclosed and an opportunity provided to contest that case. The same conclusion is not obviously correct for the Canadian regime.

\section{B The Substantive Proceedings}

The more important issue, however, is whether the substantive proceedings to which the disclosure proceedings relate involve a fair hearing. Section 19 of the NSI Act provides, in part, that:

The power of a court to control the conduct of a federal criminal proceeding, in particular with respect to abuse of process, is not affected by this Act, except so far as this Act expressly or impliedly provides otherwise. $^{68}$

\footnotetext{
${ }^{65}$ Canada Evidence Act, RSC 1985, c C-5, ss 38.04(5), 38.08. Although where this is the case there is an automatic review of the court's decision by the Federal Court of Appeal. There is again no right for the affected person to make submissions at this stage.

${ }^{66}$ Ibid s 38.13 .

${ }^{67}$ Ibid s 38.131 .

${ }^{68}$ NSI Act $\mathrm{s}$ 19(1). Section 19(3) provides the same in relation to civil proceedings.
} 
Section 19 also specifically states that a non-disclosure order does not prevent a court from staying a matter if non-disclosure 'would have a substantial adverse effect on a defendant's right to receive a fair hearing' in a federal criminal proceeding or 'would have a substantial adverse effect on the substantive hearing' in a federal civil proceeding. ${ }^{69}$ Likewise, the Canada Evidence Act also empowers a court to stay proceedings if non-disclosure would make it impossible to hold a fair criminal trial. ${ }^{70}$

One critical commentator has asked with respect to the final eleven words quoted above: 'Does this betray an admission that the drafter was aware that the provisions of the Act can be seen as an abuse of process? ${ }^{, 71}$ Whatever the answer to that question may be, the provision must be read in conjunction with the decision of the High Court in Dietrich $v$ The Queen ${ }^{72}$ the effect of which is that a court has power to order a stay of proceedings, including a permanent stay, where this is necessary to prevent an unfair criminal trial. ${ }^{73}$ Indeed, in a criminal trial subject to the operation of the NSI Act, the Supreme Court of New South Wales, in the context of considering an attack on the constitutionality of the Act, noted that '[ $\mathrm{t}]$ he traditional protections given to an accused person are not put aside by the legislation' ${ }^{74}$

It is obvious that a non-disclosure order, or an order preventing a witness from testifying, may result in an unfair trial for a number of reasons. Such an order may mean that a criminal defendant does not know the essence of the case against him or her. It may also prevent a defendant from mounting a proper defence, thus impairing his or her ability to effectively challenge the case put against him or her. This plainly does not satisfy the requirements for a fair hearing under Article 14 of the ICCPR. The question is, however, whether the power of the court to stay the proceedings erases or prevents the unfairness. In criminal cases it probably does since a stay will mean there is no chance of a conviction or criminal punishment. Indeed, a stay will mean that there is no hearing at all.

This problem arises also in civil proceedings. One former President of the Human Rights and Equal Opportunities Commission (now the Australian Human Rights Commission) put the issue in this way:

\footnotetext{
${ }^{69}$ Ibid s 19(2), (4).

${ }^{70}$ Canada Evidence Act, RSC 1985, c C-5, s 38.14.

${ }^{71}$ Anthony Gray, 'Alert and Alarmed: The National Security Information Act (Cth) (2004)' (2005) 24(2) University of Tasmania Law Review 91, 106 n 68.

${ }^{72}$ Dietrich $v$ The Queen (1992) 177 CLR 292.

${ }^{73} R v$ Lodhi (2006) 163 A Crim R 475 [90].

${ }^{74}$ Ibid [85].
} 
The power to stay proceedings would be of no comfort to a plaintiff who seeks a remedy in civil proceedings in respect of executive action that it alleged to be illegal or an abuse of process. A stay would simply defeat the action and leave the plaintiff without a remedy. ${ }^{75}$

Accordingly, the chief problem with respect to civil proceedings arises where the person to whom disclosure is sought to be denied is the plaintiff or applicant. A civil defendant is in much the same position as a criminal defendant. This is especially important since a 'civil proceeding' is defined to mean any proceeding which is not a criminal proceeding, ${ }^{76}$ thus including serious matters such as control order cases.

It is important to recognise the task of the court in deciding whether to make a non-disclosure order in a civil proceeding, and particularly to distinguish it from that same task in a criminal proceeding. Section $38 \mathrm{~L}$ of the NSI Act requires a court, in considering whether to make a non-disclosure order, to consider a number of matters. The first is whether there would be a risk of prejudice to national security if the terms of the Attorney-General's certificate were not complied with. The second matter is whether any non-disclosure order 'would have a substantial adverse effect on the substantive hearing in the proceeding'. The court may also have regard to any other matter it considers relevant. The NSI Act defines 'substantial adverse effect' to mean 'an effect that is adverse and not insubstantial, insignificant or trivial'. ${ }^{77}$ The second matter to be considered in relation to criminal proceedings is slightly different: whether a non-disclosure order would have a substantial adverse effect on the defendant's right to receive a fair hearing. ${ }^{78}$

The difference between the two matters is important. The criminal proceeding matter is limited to any substantial adverse effect on the right to receive a fair hearing. The civil proceeding matter is not so limited and extends to any substantial adverse effect on the substantive proceeding generally. It could hardly be argued that defeating an action is not a substantial adverse effect on the substantive hearing. In contrast, defeating a criminal action is unlikely to result in a complaint from a criminal defendant. Thus, in determining whether to make a non-disclosure order in a civil proceeding, the court will need to consider whether the order will have the effect of defeating the action. Whilst this consideration may not result in an order for disclosure, this does not

\footnotetext{
${ }^{75}$ John von Doussa, 'Reconciling Human Rights and Counter-terrorism - A Crucial Challenge' (2006) 13 James Cook University Law Review 104, 118.

${ }^{76}$ NSI Act s $15 \mathrm{~A}$.

${ }^{77}$ Ibid s 7.

${ }^{78}$ Ibid s 31(7)(b).
} 
render the proceedings unfair. The affected person will have been heard and the adverse effect of non-disclosure considered. Nor does it infringe the right of access to the courts, which is protected by the first sentence of paragraph 1 of Article 14 of the ICCPR. This is because the Human Rights Committee has interpreted the right of access to mean that "no individual ... [may be] deprived, in procedural terms, of his/her right to claim justice'. ${ }^{79}$ The italicised words are important. The NSI Act does not in procedural terms deprive any individual or category of individual from commencing civil proceedings. Equally, the NSI Act does not have the purpose or effect of 'systematically frustrat[ing]' a particular individual's attempts to access the courts ${ }^{80}$ since it is a statute of general application.

Moreover, the European Court of Human Rights has held that the "right [of access to a court] is not absolute, but may be subject to limitations'. ${ }^{81}$ Such limitations must not impair the 'very essence' of the right and must pursue a legitimate aim, with a reasonable proportionality existing between the means employed to effect the limitation and the aim sought to be achieved. ${ }^{82}$ The NSI Act does not impair the very essence of the right of access to the courts in that it does not prevent the commencement of any proceedings but, rather, merely provides a procedure for determining whether certain sensitive information should be disclosed. The Act requires the potential of defeating an action by a non-disclosure order to be considered before such an order is made. It does not appear to be the case that a system whereby a court makes a non-disclosure order after considering the effect of such an order is a disproportionate means of achieving the aim of guarding against risks of prejudice to national security. ${ }^{83}$

\footnotetext{
${ }^{79}$ General Comment No 32, UN Doc CCPR/C/GC/3, [9] (emphasis added).

${ }^{80}$ General Comment No 32, UN Doc CCPR/C/GC/3, [9]; Human Rights Committee, Views: Communication No 468/1991, 49 ${ }^{\text {th }}$ sess, UN Doc CCPR/C/49/D/468/1991 (10 November 1993, adopted 20 October 1993) annex [9.4] ('Oló Bahamonde v Equatorial Guinea').

${ }^{81}$ Kulikowski v Poland (European Court of Human Rights, Fourth Section, Application no 18353/03, 19 May 2009) [58].

${ }^{82}$ Ibid.

${ }^{83}$ NSI Act $\mathrm{s} 3$.
} 


\section{THE REQUIREMENT FOR DETERMINATION BY A COMPETENT, INDEPENDENT AND IMPARTIAL TRIBUNAL ESTABLISHED BY LAW}

The second core protection of Article 14 requires that the determination of any criminal charge, or of rights and obligations in a suit at law, be by a competent, independent and impartial tribunal established by law. The Human Rights Committee considers this to be 'an absolute right that is not subject to any exception'. ${ }^{84}$ At the outset, it can be stated that the NSI Act does not seek to have any issue determined by a tribunal that is not competent (in the sense of being properly possessed of jurisdiction) ${ }^{85}$ or established by law. What needs to be considered is whether the NSI Act requires the determination of issues by a tribunal that is not 'independent' and 'impartial'.

\section{A Independence}

The Human Rights Committee has held that the requirement of independence refers to a number of important guarantees. Most relevantly for present purposes, the requirement of independence includes 'the actual independence of the judiciary from political interference by the executive branch and legislature' and the inability of those entities to 'control or direct' the judiciary in the performance of its functions. ${ }^{86}$ The European case law also indicates that the executive must not be able to issue instructions to the judiciary in its adjudicatory function. ${ }^{87}$ The European Court of Human Rights has also considered that the appearance of independence is required. ${ }^{88}$

In Campbell and Fell v United Kingdom the European Court of Human Rights considered a complaint that a Board of Visitors in the United Kingdom was not 'independent'. ${ }^{89}$ A Board of Visitors is a lay tribunal established to hear

\footnotetext{
${ }^{84}$ General Comment No 32, UN Doc CCPR/C/GC/3, [19]; Human Rights Committee, Decision: Communication No 263/1987, $46^{\text {th }}$ sess, UN Doc CCPR/C/46/D/263/1987 (2 November 1992) annex [5.2] ('Gonzalez del Rio v Peru').

${ }^{85}$ Richard B Lillich, 'Civil Rights' in Richard Pierre Claude and Burns H Weston (eds) Human Rights in the World Community, (University of Pennsylvania Press, 3rd ed, 2006), 93, 100.

${ }^{86}$ General Comment No 32, UN Doc CCPR/C/GC/3, [19].

${ }^{87}$ Stephanos Stavros, The Guarantees for Accused Persons under Article 6 of the European Convention on Human Rights: An Analysis of the Application of the Convention and Comparison with Other Instruments, 139.

${ }^{88}$ Campbell and Fell v United Kingdom (1984) 80 Eur Court HR (ser A) [78]; Delcourt v Belgium (1970) 11 Eur Court HR (ser A) [31]; Bryan v United Kingdom (1995) 335-A Eur Court HR (ser A) [38].

${ }^{89}$ Campbell and Fell v United Kingdom (1984) 80 Eur Court HR (ser A).
} 
and determine disciplinary proceedings against prisoners. In the course of rejecting the complaint for a number of reasons, the Court referred to the fact that the Home Office had issued guidelines as to the conduct of Board proceedings. The guidelines in question were contained in a booklet entitled 'Procedure for the Conduct of an Adjudication by a Board of Visitors' and concerned the general steps to be followed in conducting an adjudication. ${ }^{90}$ The Court said: '[A]lthough it is true that the Home Office may issue Boards with guidelines as to the performance of their functions..., they are not subject to its instructions in their adjudicatory role. ${ }^{, 91}$ This is consistent with the position of the Human Rights Committee that independence requires an absence of control or direction in the exercise of a court's adjudicatory functions.

It has been argued that the role of the court under the NSI Act in making orders on the question of disclosure of information is mere 'window dressing' and a 'sham' that disguises the reality that the court's decision-making is controlled by the executive. ${ }^{92}$ If this is correct then the Article 14 requirement of independence is not satisfied. Section 31(7) of the NSI Act provides that in deciding whether to make a non-disclosure order, and, if so, in what form, a court must consider three matters. First, whether, having regard to the Attorney-General's certificate, there would be a risk of prejudice to national security if non-disclosure in the form outlined in the certificate is not required. Second, whether the order to be made would have a substantial adverse effect on the defendant's right to receive a fair hearing, including in particular an effect on the conduct of his or her defence. Third, any other matter the court considers relevant. Section 37(8) provides that '[i]n making its decision, the Court must give greatest weight' to the first matter. Section 38L(7) and (8) is in similar terms for the purposes of federal civil proceedings.

In $R v$ Lodhi, ${ }^{93}$ the Supreme Court of New South Wales had occasion to consider the operation of section 37(7) and (8). Justice Whealy rejected the argument that the discretion in section 31 was simply a pretended discretion. His Honour considered that 'there is no suggestion, on the proper construction of s 31(7) and (8) that the certificate is conclusive or determinative of the issue' and that 'the Court is free to form a view that is entirely contrary to the tenour of the certificate' ${ }^{94}$ His Honour also held that ' $[r] e a d$ fairly, it seems to me that the legislation does no more than to give the Court guidance as to the

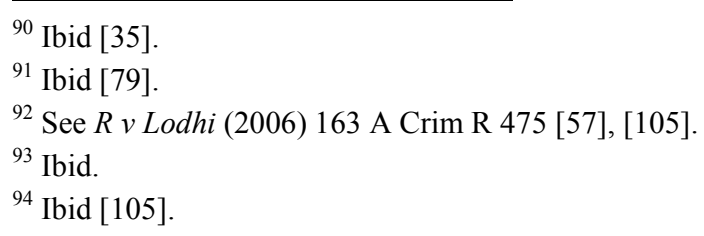


comparative weight it is to give one factor when considering it alongside a number of others'. ${ }^{95}$ If this interpretation is correct, then the NSI Act would not appear to control or direct the court in the exercise of its adjudicatory functions. However, this interpretation has been contested. Michael McHugh, a former judge of the High Court of Australia, has said:

It is no doubt true that in theory the National Security Information (Criminal and Civil Proceedings) Act 2004 does not direct the court to make the order which the Attorney wants. But it goes as close to it as it thinks it can. It weights the exercise of the discretion in favour of the Attorney-General and in a practical sense directs the outcome of the closed hearing. How can a court realistically say I am going to make an order in favour of a fair trial even though, in exercising my discretion, I give the issue of fair trial less weight than the Attorney-General's certificate. Imagine the appellate fate of a custody order where the trial judge has said I give custody to the father although his claim has less weight than that of the mother. ${ }^{96}$

Gray, an academic commentator, has suggested that '[w]hile the defendant's right to a fair trial is specifically mentioned as a factor [to be taken into account], the matter to which most weight must be given is the AttorneyGeneral's certificate'. ${ }^{97}$ Gray also comments that 'a court cannot be asked in one breath to consider a matter, but in the next breath be told that the view of the Attorney-General on the matter is the overriding consideration. That does, with respect, appear to place judges in a position of subservience to the executive. ${ }^{98}$

It appears that the concerns of McHugh and Gray are both in important respects misconceived. The matter to which most weight must be given is not the Attorney-General's certificate. Sub-section 8 provides that the matter to which most weight is to be given is whether there would be a risk of prejudice to national security if the terms of the certificate were not complied with. In answering that question, the court must only have 'regard' to the AttorneyGeneral's certificate. The certificate is not determinative of the question of risk. ${ }^{99}$ Thus, in the words of Whealy $\mathrm{J}$, 'the legislation does no more than to

\footnotetext{
${ }^{95}$ Ibid [108].

${ }^{96}$ Michael McHugh, 'Constitutional Implications of Terrorism Legislation' (2007) 8 Judicial Review 189, 209.

${ }^{97}$ Gray, above n 71, 98 .

${ }^{98}$ Ibid 100.

99 NSI Act s 27(1) makes clear that the certificate is only so conclusive up until the commencement of the hearing in which the court considers whether or not to make a nondisclosure order.
} 
give the Court guidance as to the comparative weight it is to give one factor when considering it alongside a number of others'. ${ }^{100}$

This is a view that has been confirmed by the New South Wales Court of Criminal Appeal. ${ }^{101}$ The Court of Criminal Appeal considered that, while subsection 8 guides the court in its task of balancing the competing interests identified in sub-section 7 ,

[t]he existence of such guidance, even if it can be said to tilt the balance in favour of a particular decision, does not fundamentally alter the task ... [I]t is important to recognise that tilting the balance by some form of guidance is perfectly consistent with the traditional judicial decision making process. $^{102}$

Whilst the guidance given by sub-section 8 goes beyond that provided in Campbell and Fell, which concerned procedural steps, the guidance does not amount to an instruction since the court is required to come to its own conclusion about the relevant risk of prejudice to national security and then about the question of disclosure. It is not instructed to make a particular finding. It is not subject to external control or direction. The independence of the court therefore does not appear to be impaired by sub-section 8 . Whether, as a matter of public policy, there should be less guidance given to the court is a separate question.

Furthermore, the decision of the court as to disclosure is not open to reversal by the executive. ${ }^{103}$ If it were, then questions might arise as to the true independence of the court. This is because 'the power to give a binding decision which may not be altered by a non-judicial authority' is a component of independence. ${ }^{104}$ This requirement appears to be violated by the regime established in Canada by the Canada Evidence Act 1985 which, while giving power to the Federal Court of Canada to make orders regarding nondisclosure of national security sensitive information to a defendant, also empowers the Canadian Attorney-General to issue a non-disclosure certificate prohibiting disclosure which takes effect even in the face of a court decision

\footnotetext{
${ }^{100} R v$ Lodhi (2006) 163 A Crim R 475 [108].

${ }^{101}$ Lodhi v The Queen (2007) 179 A Crim R 470 [36].

${ }^{102}$ Ibid [41]. See also [45], [67], [73].

${ }^{103}$ In the face of an order under the NSI Act requiring disclosure, the executive could only avoid that obligation in a criminal proceeding by discontinuing the prosecution in order to avoid the occasion for disclosure. This is plainly not the same as reversing the order.

${ }^{104}$ Van de Hurk $v$ Netherlands (1994) 288 Eur Court HR (ser A) [45]; Findlay v United Kingdom [1997] I Eur Court HR [77].
} 
in favour of disclosure. ${ }^{105}$ Unlike the situation under the Australian legislation, the decision of a Canadian court as to disclosure stands only if the Attorney-General allows it to.

\section{B Impartiality}

The next issue to be considered is whether the NSI Act can be seen as allowing the determination of a criminal charge or rights and liabilities in a suit at law by a tribunal that is not impartial. At first glance, the answer would appear to be obviously 'no'. The requirement of impartiality has been interpreted by both the Human Rights Committee ${ }^{106}$ and by the European Court of Human Rights ${ }^{107}$ in terms broadly consistent with the bias rule in Australian law. The NSI Act plainly does not seek to exclude the operation of that rule. However, it is necessary to consider more fully the nuances of the international jurisprudence to reach any firm conclusion. Stavros has summarised the effect of the European jurisprudence relating to impartiality and concluded that 'knowledge of the case acquired through ... certain judicial functions which involve a pronouncement on the merits creates a presumption of bias against the judge who subsequently hears the case'. ${ }^{108}$

One of the more important European impartiality cases is Hauschildt $v$ Denmark. ${ }^{109}$ In that case, the applicant complained that he had not had the benefit of an impartial tribunal on the ground that the judge who convicted him made a number of pre-trial decisions relating to remand and that, accordingly, the judge's appreciation of the evidence at the subsequent trial was coloured. The Court held that making remand decisions based on the existence of a prima facie case does not create an impression of partiality where the same judge later goes on to determine the question of guilt on the ordinary standard. ${ }^{110}$ The Court went on to hold, however, that 'special circumstances' in a particular case may warrant a different conclusion. ${ }^{111}$ In Hauschildt the judge made nine decisions regarding remand. ${ }^{112}$ Each of those decisions required the judge to be convinced that that there is a 'very high

\footnotetext{
${ }^{105}$ Canada Evidence Act, RSC 1985, c C-5, s 38.13.

106 General Comment No 32, UN Doc CCPR/C/GC/3, [21]; Human Rights Committee, Decision: Communication No 387/1989, $46^{\text {th }}$ sess, UN Doc CCPR/C/46/D/387/1989 (5 November 1992) annex [7.2] ('Karttunen $v$ Finland') .

${ }^{107}$ Piersack v Belgium (1982) 53 Eur Court HR (ser A) [30].

${ }^{108}$ Stavros, above n 89, 155.

${ }^{109}$ (1989) 154 Eur Court HR.

${ }^{110}$ Ibid [50].

${ }^{111}$ Ibid [51].

${ }^{112}$ Ibid .
} 
degree of clarity' as to the question of guilt. ${ }^{113}$ The Court concluded, 'Thus the difference between the issue the judge has to settle when ... [making remand decisions] and the issue he will have to settle when giving judgment at the trial becomes tenuous. ${ }^{114}$ The Court concluded that this gave rise to an appearance of partiality.

Under the NSI Act the trial judge is required to come to a conclusion as to the effect of non-disclosure of particular information on the right of a defendant to receive a fair hearing, including in particular on the conduct of his or her defence, as a step along the way to determining the issue of disclosure. ${ }^{115}$ Depending on the view of a fair hearing adopted, there is the potential for the judge to act in a partial way by coming to such a conclusion. The decision of the House of Lords in Secretary of State for the Home Department $v M B^{116}$ suggested, somewhat vaguely, that decisions on the question of disclosure of sensitive information could be based, in part, on an analysis of whether disclosure would make any difference to the defendant's case. ${ }^{117}$ There was suggestion in the opinions of more than one of their Lordships, and later acceptance by first instance courts, ${ }^{118}$ that if the case for the imposition of a control order on the disclosed materials against a person was so cogent as to allow a judge to feel 'quite sure that in any event no possible challenge could conceivably have succeeded" ${ }^{119}$ then the case for disclosure of sensitive information was weakened.

If this reasoning were to be applied to the analysis to be undertaken under the NSI Act then in doing so the judge will have effectively prejudged the substantive case in a manner rebuked in Hauschildt. As noted above, the prevailing jurisprudence of the European Court of Human Rights and the House of Lords, which is consistent with that of the Human Rights Committee, requires disclosure of the essence of the case against a person and an effective opportunity to challenge that case. This rule has no room for a 'makes no difference' principle. ${ }^{120}$ The purpose of considering the 'makes no difference' notion is to demonstrate the potential for unfairness in the disclosure regime established by the NSI Act. This potential, however, is

\footnotetext{
${ }^{113}$ Ibid [52].

${ }^{114}$ Ibid.

${ }^{115}$ NSI Act s 31(7)(a)(ii).

116 [2007] UKHL 46.

117 Secretary of State for the Home Department v MB [2007] UKHL 46, [65], [90]; and see Secretary of State for the Home Department v AF [2009] UKHL 28 [19].

${ }^{118}$ See, eg, Secretary of State for the Home Department v AN [2008] EWHC 372 (Admin) [9].

${ }^{119}$ Secretary of State for the Home Department $v$ MB [2007] UKHL 46 [90].

${ }^{120}$ Secretary of State for the Home Department $v$ AF [2009] UKHL 28 [63].
} 
unlikely ever to be realised. The reason follows from the fact that the NSI Act does not seek to exclude the operation of the ordinary bias rule. Since it is the plain purpose of the NSI Act, in contrast to the Canada Evidence Act, ${ }^{121}$ to have questions of disclosure determined by the trial judge, it would be frustrating the purpose of the Act to interpret it in such a way as to potentially require a trial judge to act in a manner that would force him or her to stand aside from hearing the substantive case. The NSI Act therefore would not appear to violate the requirement of impartiality.

\section{CONCLUSION}

The right to a fair hearing is fundamental to a free society and is protected by international law. At a time when heightened concerns about terrorism are prominent there is a risk that that right may be impaired on grounds of expediency. In a well known decision Sir Robert Megarry said:

It may be that there are some who would decry the importance which the courts attach to the observance of the rules of natural justice. 'When something is obvious,' they may say, 'why force everybody to go through the tiresome waste of time involved in framing charges and giving an opportunity to be heard? The result is obvious from the start.' Those who take this view do not, I think, do themselves justice. As everybody who has anything to do with the law well knows, the path of the law is strewn with examples of open and shut cases which, somehow, were not; of unanswerable charges which, in the event, were completely answered; of inexplicable conduct which was fully explained; of fixed and unalterable determinations that, by discussion, suffered a change. Nor are those with any knowledge of human nature who pause to think for a moment likely to underestimate the feelings of resentment of those who find that a decision against them has been made without their being afforded any opportunity to influence the course of events. ${ }^{122}$

Ultimately, it is principles like these that underlie the right to a fair hearing protected by Article 14 of the International Covenant on Civil and Political Rights ${ }^{123}$ which is binding on Australia.

The National Security Information (Criminal and Civil Proceedings) Act 2004 (Cth) altered the way in which questions relating to the disclosure of national

\footnotetext{
${ }^{121}$ RSC 1985, c C-5.

${ }^{122}$ John v Rees [1970] Ch 345, 402.

${ }^{123}$ Opened for signature 19 December 1966, 999 UNTS 171 (entered into force 23 March 1976).
} 
security-sensitive information in proceedings arising in federal jurisdiction are to be handled. The legislation, whilst perhaps not perfect, does not appear to violate the fundamental requirements of the right to a fair hearing. 